\title{
Financial Liberalisation in Emerging Markets: How Does Bank Lending Change?
}

\author{
Olaf Hübler, Lukas Menkhoff and Chodechai Suwanaporn
}

\author{
Discussion Paper 364 \\ May, 2007 \\ ISSN: 0949-9962
}

\begin{abstract}
Financial liberalisation has often failed in the past due to underestimated problems of structural change. We analyse such changes in lending behaviour of Thai commercial banks during a liberalisation phase by way of unique micro data. Liberalisation has expected positive effects, such as lowering the interest rate spread and collateral requirements. Liberalisation causes structural change, such as a decline in collateralbased and relationship banking. However, the liberalisation evidence is consistent with more risk taking, such as lending to more risky projects and less protection against default. The Thai experience suggests obvious policy lessons.
\end{abstract}

\author{
JEL-Classification: $\quad$ O 16, F 30, G 21 \\ Keywords: \\ financial liberalisation, lending decisions, emerging economies, \\ Thailand
}

15 March, 2007

OLAF HÜBLER, Leibniz Universität Hannover, Germany and IZA, Bonn, Germany; LUKAS MENKHOFF, Leibniz Universität Hannover, Germany; CHODECHAI SUWANAPORN, Chulalongkorn University, Thailand

We gratefully acknowledge very constructive comments by an anonymous referee, comments at several seminars and at the Annual Conference of the German Economic Association 2005 in Bonn. Maik Schmeling provided very useful research assistance. Financial support by the Center for Development Research at the University of Bonn (ZEF Bonn) and by the German Academic Exchange Service (DAAD) is gratefully acknowledged. 


\section{INTRODUCTION}

The 1980s and 1990s witnessed waves of domestic and external financial liberalisation in numerous countries. Financial liberalisation is regarded as an efficient means to foster competition and to invite growth impulses from abroad (see Bartolini and Drazen, 1997). The downside of liberalisation is its shock effect on institutional settings, possibly destabilising the economy (Demirgüç-Kunt and Detragiache, 1999; Kaminsky and Reinhart, 1999). In summary, liberalisation tends to produce higher growth but also higher volatility so that a trade-off may be inherent (Tornell and Westermann, 2005). In order to improve such a trade-off by appropriate policy measures it appears warranted to learn more about the impact of financial liberalisation on the lending behaviour of banks which are the core financial group in emerging economies. Whereas earlier studies focus on aggregate changes in banks' policies, such as changes in total credit volume, our study is novel - to the best of our knowledge - in analysing banks' credit files in a phase of financial liberalisation. This micro data of lending behaviour provides a richer picture on liberalisation-induced changes in bank lending than macro-analyses can do. Due to this advantage we can identify opportunities and risks of financial liberalisation more precisely which accordingly allows to draw better targeted policy recommendations.

Financial liberalisation has been intensively studied during the past but there is still no consensus on its consequences. Whereas some studies emphasise positive impacts (for example Fry, 1997; Quinn, 1997; World Bank, 2001; Henry, 2006), others point at inherent risks (for example Stiglitz, 2000, 2004; Cull, 2001; Demetriades and Luintel, 2001; Weller, 2001). Summarising, Auerbach and Siddiki (2004, p.231) state that "the near unanimity of international agencies in their call for financial liberalisation is not echoed in the academic literature". Eichengreen (2001, p.341) assesses external financial liberalisation - which is particularly important in our case as "one of the most controversial and least understood policies of our day".

Studies on financial liberalisation often employ cross-country regressions. We have learned, however, that the average effects found can hide completely different experiences (Demetriades and Hussein, 1996; Arestis et al., 2002; Aizenman, 2005). Therefore, studies based on micro-level data, such as examining the impact of liber- 
alisation on bank lending behaviour, should be of interest but they are in short supply. ${ }^{1}$ It seems thus well motivated to contribute to filling this gap in the literature.

Our study is based on an empirical analysis of the Thai situation in the 1990s which is quite representative for liberalisation episodes in emerging markets. Thailand belongs to the group of middle-income economies which typically have a bankbased financial system. Accordingly, we analyse the lending behaviour of Thai commercial banks which dominate financial institutions in the country. Commercial banks commanded over about 60 per cent of financial institutions' assets in the early 1990s, the remaining share being divided between finance companies (specialised near-banks) and other specialised banks, mainly state-owned. Due to a strict regulatory policy only 5 per cent of commercial banks' assets used to belong to foreign banks operating from Bangkok. The lending behaviour of Thai commercial banks is covered in this study during Thailand's phase of financial liberalisation between 1992 and 1996 (see Kaminsky and Schmukler, 2002, Table 1). We restrict our sample to end in 1996 since the Asian crisis began in July 1997 and would distort our yearly data.

As an analytical framework to measure possible changes in bank lending behaviour we rely on the relationship banking literature where benchmark studies have been Petersen and Rajan (1994) or Berger and Udell (1995). Relationship banking means that a lasting relation between bank and borrower impacts the lending contract (Boot, 2000). An important motivation to keep lasting relations is to reduce the information asymmetry between lender and borrower. As information is more opaque in emerging countries, the concept of relationship banking is expected to be particularly appropriate for their institutional situation and has been usefully applied recently by La Porta et al. (2003). We go a step beyond these earlier studies by analysing two dimensions of lending decisions - that is interest rate and collateral - in a simultaneous regression approach. ${ }^{2}$

\footnotetext{
Eichengreen (2001) as well as Bekaert et al. (2005) each mention a wealth of studies based on firm data but they do not refer to a single study based on (micro-level) bank data to analyse (external) financial liberalisation.

2 This is also progress from earlier papers based on the same data which either focus on relationship lending (Menkhoff and Suwanaporn, 2007) or on the role of collateral (Menkhoff et al., 2006). The second innovation of this paper is the analysis of changes in lending behaviour over the time-period 1992-96 whereas former work had analysed variable averages only.
} 
It is indeed found that changes in banks' behaviour matter in a systematic way. Findings are by and large consistent with theoretically expected impacts of financial liberalisation. The good news is that liberalisation makes borrowing cheaper and easier as it decreases interest rate spreads and reduces collateral requirements. Moreover, financial liberalisation also modernises the financial system by enlarging the power of market forces at the cost of traditional institutions, here reflected in a declining importance of collateral-based and relationship lending. However, the intended changes seem to come at a price, i.e. increased risks stemming from two sources. First from a macro viewpoint, banking becomes more risky by greater interest rate and exchange rate changes (see Stiglitz, 2004, in general, and Menkhoff, 2000, for Thailand). Second from a micro viewpoint, lending may become more risky due to a change indicated by our analyses. One element of this change is that banks seem to finance more risky projects (although our data are lacking unequivocal information about riskiness). The other element is that banks take less caution to protect themselves against default of borrowers. Moreover, banks did not upgrade their risk management and obviously regulatory policy did not provide the necessary incentives for improvement. Our case study thus reflects the often ambiguous findings from the cross-country regressions. It suggests, moreover, that appropriate risk management capabilities may be the decisive factor of success, which in turn points at the most important role of institution building in combination with financial liberalisation (e.g. Bongini et al., 2001).

The line of argument proceeds in the following steps: Section 2 reviews in short the respective literature on possible effects of financial liberalisation on banks' lending behaviour and derives hypotheses to be tested. Section 3 describes data and methodology applied. Empirical results are presented and discussed in Section 4 . Section 5 concludes.

\section{A SELECTIVE LITERATURE REVIEW AND HYPOTHESES}

Financial liberalisation is a policy to open up closed domestic financial markets. In the narrower case of external financial liberalisation domestic markets are opened to the world economy. This new environment drastically increases (the number of) financing alternatives for companies. New domestic competitors may enter the market, already existing financial institutions may increase their scope of action and new instruments may become available. In the case of external financial liberalisation, the 
international capital market becomes accessible and prices being paid for the use of capital decline. A company can expect higher prices when issuing new shares and better offers when floating bonds internationally. This alone puts domestic banks under enormous pressure. Competitive pressure increases even more when foreign banks are allowed to enter the market and offer directly comparable services to domestic banks (see Claessens et al., 2001; Gelos and Roldós, 2004). Then companies profit from several effects: they can tap the (international) capital market or they can turn to either new domestic competitors or foreign banks which will always ease possible credit rationing and contribute to a declining price for capital.

As such a change involves several market segments, financial liberalisation will usually be a process lasting for years. Many studies just take one date which is regarded as the most important and as many studies focus on the stock market, the respective date for Thailand's capital account opening is usually during the years $1988 / 89$, when this market became more open to foreigners. Seen from the perspective of Thai banks, however, this may not be the decisive period. Imagine, for example, that interest rates were still liberalised until 1991. Moreover, regarding external financial liberalisation in Thailand, Kaminsky and Schmukler (2002) date a second period from 1992 to 1997. If one would like to pinpoint a certain year during the 1990s, it is definitely the year 1993 that had the greatest effect for domestic banks.

In this year foreign banks were allowed to operate from within Thailand by way of the so-called "Bangkok International Banking Facilities" (BIBF). This policy measure drastically altered the situation of domestic banks as foreign competitors were thus allowed to leave their quarter of a restricted 5 per cent market share (see Charoenseang and Manakit, 2002). The number of banking licenses for foreign banks more than doubled and their active operations can be seen from the steady increase in market share: over a three-year period from early 1993 to early 1996 foreign banks almost tripled their market share with momentum picking up in the second half of 1993. As this figure measures assets, it is obvious that the swing in flows must have been even more dramatic. New credits of foreign banks increased ten-fold from 1992 to 1994 (see Menkhoff, 2000).

The shift in the banks' market coincided with other changes. First, portfolio investments gained another dimension during the second half of 1993 with roughly 1 bn. USD per quarter until the middle of 1996 compared with roughly $0.2 \mathrm{bn}$. USD per quarter during the years up to 1993. This means the international capital market be- 
came another important source of financing. In addition to these consequences of external liberalisation and favourable investment climate, the domestic financial liberalisation made home capital markets more attractive and gave finance companies increased scope of action. Thus, the market share of Thai commercial banks in providing new external funds for private non-financial companies steadily decreased during the early 1990s. It went down from the pre-BIBF period of 1992/93 to the postBIBF-introduction period of 1994/95 from more than 60 per cent to less than 50 per cent (see Menkhoff, 2000, Table 3).

These data show that Thai banks were under steady competitive pressure during the early 1990s. Which effects of Thailand's financial liberalisation during the period 1992-96 can be expected on bank lending behaviour? We put the effects in the form of three hypotheses and arrange the remaining discussion in Section 2 accordingly: financial liberalisation is expected to improve first, the terms of bank lending, such as lower pricing, second, to modernise the way of how banking is conducted, such as reducing the importance of traditional relationship banking, and third, to possibly increase riskiness in lending policy.

$\mathbf{H}_{\mathbf{1}} \quad$ Financial liberalisation improves the terms of bank lending for the borrowers.

The terms of bank lending have at least two major dimensions that is the pricing of loans and the necessary provision of collateral. The expected signs of change which can be empirically tested are justified as follows: as closed markets usually have a lesser degree of competition and as the foreigners entering the market apply advanced credit granting technologies, the opening is expected to make markets more efficient and to improve their benefits for the overall economy. On the macroeconomic level, one would expect a strong capital inflow from external financial liberalisation and, eased by these inflows, also an increase in loan volume. This sequence is indeed a stylised fact happening also in Thailand (Jansen, 2004). Regarding the price of bank lending, financial opening is expected to generate a decreasing interest rate spread in credit markets, keeping other determinants constant.

A second dimension is the amount of collateral that is required by the lending bank. Collateral can be seen as a technically easy-to-handle form of risk insurance which may thus be particularly appropriate in developing economies (Menkhoff et al., 2006). This view would classify collateral-based lending as an advanced pawn-shop business. Assuming that banks compete harder and improve their technologies after 
financial liberalisation, a tendency towards lower collateral requirements may be expected.

Collateral-based lending thus has two aspects: first, it reduces opportunities for borrowers and thus is a cost from their perspective and second, it may be regarded as a particularly simple form of lending. The first aspect is addressed by hypothesis 1 and the second better fits to hypothesis 2 , that is, the desire to modernise the banking sector by way of financial liberalisation.

$\mathbf{H}_{2} \quad$ Financial liberalisation reduces the importance of traditional elements in bank lending.

To bring emerging markets closer towards world standards necessarily implies further qualitative changes besides a possibly reduced reliance on collateral. To simplify the argument, let us assume stylised institutional differences between an emerging and a mature bank lending market. Most important is the lower degree of available reliable information in emerging markets leading to stronger asymmetric information between lending banks and borrowing firms (Frenkel and Menkhoff, 2004). A traditional and rational form of coping with strong asymmetric information in lending is to establish lasting lending relationships (Boot, 2000). In this sense, pronounced relationship banking in emerging markets is a consequence of its institutional characteristics. It also follows from this reasoning that the change of these markets towards international common standards - including more competition - is accompanied by institutional reforms reducing the importance of relationship lending (see also Petersen and Rajan, 1995). This can be tested by observing possible changes in relationship proxies as determinants of bank lending over time.

The expected progress of financial liberalisation on bank lending has, however, the possible downside risk of an overshooting in the sense that easier lending terms lead to an overly optimistic provision of capital. There is, indeed, empirical evidence that financial liberalisation is often followed by financial fragility (for example, Williamson and Mohar, 1998, Kaminsky and Reinhart, 1999).

$\mathbf{H}_{3} \quad$ Financial liberalisation may (temporarily) increase the riskiness in bank lending.

The effect of financial liberalisation on the effective risk consideration in bank lending is ambivalent: on the positive side there is the fact that financial opening provides better opportunities for developing hedging instruments and improving the asset-liability-management of a bank. Moreover, increased competition by technologically advanced foreign banks creates a strong incentive for domestic banks to im- 
prove their risk management abilities in order to be more competitive relative to the new market entrants (see World Bank, 2001). On the negative side, it is argued that a net benefit depends on the comparative development of risk management abilities with increasing demand on it. For example, better diversification due to investments in new markets and new currencies is only helpful if these new markets are understood properly (see Chari and Henry, 2002).

Another line of argument questioning better risk consideration in response to financial liberalisation stresses the ambivalent consequences from increased competition. A possible response of bank management towards tougher competition could be trying to compensate declining interest rate margins by shifting the loan portfolio towards higher risk without fully pricing these higher risks. As a consequence, the overall credit volume boom would then be accompanied by a weakening of loan quality and thus increased fragility of these institutions.

Summing up theoretically derived expectations, financial liberalisation can enormously change bank lending and thus decide about welfare effects of liberalisation. We hypothesise about three possible changes which may conveniently be thought of as better lending terms $\left(\mathrm{H}_{1}\right)$, more modern lending behaviour $\left(\mathrm{H}_{2}\right)$ and increased riskiness in lending $\left(\mathrm{H}_{3}\right)$. Empirical tests will show which of these hypotheses hold in the light of the Thai experience.

\section{DATA AND METHODS}

\section{a. Data Compilation}

To conduct a study about lending behaviour of Thai banks, we have compiled a new data set of credit files that is by and large representative and reliable for the industry. These data are highly confidential and thus difficult to obtain. Another obvious problem in the Thai case is the poor performance of the lending business, resulting in a share of non-performing loans (NPL) of more than 50 per cent in the industry at the end of the 1990s, which may make the bankers even more hesitant to provide any information to outsiders. There are, however, also helpful factors in obtaining the data: some years have passed between credit granting and data collection and during the years procedures have been upgraded and the responsible management has changed. Moreover, participation in the study is kept strictly confidential and the purpose is purely academic. 
The data for our examination come from a survey study being conducted with Thai commercial banks in the years 2000/01, yielding a sample that represents banks from all size categories. All 15 relevant banks had been contacted and nine of them agreed to provide between 35 and 85 of their credit files. One selection criterion for credit files was to cover credit granting decisions within the pre-crisis period from 1992 to 1996. Another criterion was to cover all kinds of industries. Regarding the process of file collection, we could usually select files from the total universe of customers. The selection process aimed for a randomised sample.

In summary, we received 560 useful cases of which we use here 550 due to some missing values. This data set has been analysed in several respects and shows an inherently reasonable structure. Crosschecks with data for the Thai economy prove that it is a useful sample (see details in Menkhoff and Suwanaporn, 2007). Reassuringly, the three remaining distortions are acceptable: first, the loan cases are a bit too favourable for the industry as the NPL ratio is 45.9 per cent in the sample, whereas it reached more than 50 per cent for the total. Second, industries are not perfectly matched, as the manufacturing and the real estate sector are overrepresented, whereas trade and consumption loans in particular are underrepresented. Third, company size and the corresponding loan size are above the countries' average, as credit files were collected from the banks' headquarters and thus do not reflect smaller loans in rural areas.

\section{b. Data Description}

The variables employed in the following analysis resemble standard variables from the literature on bank lending behaviour (see in detail Table 1). At the beginning of the table are the two dependent variables informing about different dimensions of lending decisions, that is the interest rate spread and the collateral required. The independent variables consist of three relationship variables which have been suggested in the literature (the third of them is used in robustness tests only), company variables, other variables and time variables. We have deliberately not considered possible direct risk variables, such as company leverage (debt to equity capital), as these measures were not important according to earlier research (Menkhoff and Su- 
wanaporn, 2007). ${ }^{3}$ Other variables include measures to capture possible advantages of larger banks and variables that are basically motivated by statistical reasons: an outlier term is incorporated together with industry dummies. The time variables consist of, first, a simple linear time trend and, second, three interaction variables in order to get hold of changes between the earlier liberalisation period of 1992/93 and the later period of 1994-96 where liberalisation consequences became fully effective. Some of these data are transformed slightly in accordance with earlier studies (in particular Petersen and Rajan, 1994). ${ }^{4}$

As this study on the impact of financial liberalisation is interested in the time dimension, mean values and standard deviations of all variables are given year by year in Table 2. One can see with regard to the hypotheses of interest that the changes in the interest rate spread and in collateral requirements run rather against expectations. Another impression of changes due to financial liberalisation can be gained by splitting the sample into a pre- and a post-BIBF-introduction period. The results in Table 3 show that 140 of the 550 cases stem from the pre-phase and the other 410 from the post-phase. The descriptive statistics of the two lending dimension variables again do not confirm our hypothesis 1 . We had expected that lending conditions would have improved after liberalisation, showing lower interest rates and less collateral requirements. We observe, however, on average higher interest rate spreads and higher collateral requirements, both being statistically significant.

\section{c. Simultaneity in Decision Making}

The next step is to consider simultaneity. Interdependencies between the two dimensions in lending decisions - pricing and collateral - are most plausible. Assume for example that increased competition forces Thailand's banks to reduce the interest rate just as desired by financial liberalisation. Domestic banks thus receive less income from interest-sensitive business, a change to which they can react by several strategies. First, they may interpret declining income from loans as a declin-

\footnotetext{
3 Also earlier studies in the US had problems identifying risk factors that influence pricing from the perspective of the bank (see Petersen and Rajan, 1994; Berger and Udell, 1995). The situation becomes different when banks use internal risk ratings which are closely related with interest rate spread. A methodological problem with this kind of information is its possibly tautological character. Nevertheless, it is telling that such internal ratings did not seem to be used in Thai banks' practice until 1996.

${ }^{4}$ The asset size variable and the number of borrowing banks are usually taken in logarithmic form due to their right-skewed distribution.
} 
ing possibility to cover loan losses which might lead to more risk-averse lending decisions. Higher risk aversion may be recognised from higher collateral requirements. A second strategy might be trying to gain market share in order to increase the coverage of fixed costs. This would lead to rather lower collateral requirements. The banks could also choose a mixture of both instruments. In this way, a trade-off or a complementary relationship between the interest rate spread and collateral may be found.

If there are interdependencies between the two dimensions in lending, an empirical examination should consider the endogeneity of dependent variables. The application of a simultaneous estimator, that is the three-stage least squares (3SLS) method, is then an appropriate approach (Greene, 2003, pp. 405).

\section{d. Measuring Effects of Financial Liberalisation}

We determine liberalisation effects by time-related (interaction) variables. This approach includes interaction variables between a time dummy and determinants of our two equation model. This implicitly assumes that liberalisation is not immediately (1993) effective but rather from 1994 onwards. Therefore, the time dummy is defined as 1 , if the observation stems from 1994 or later, and as 0 otherwise. As an additional element to capture possible liberalisation effects which might show up in a more continuous form, we add a time trend variable to the basic regressions.

The major advantage of this approach is that the liberalisation effects can immediately be determined, namely by the coefficients of the time-related variables. The disadvantage is that it is not sensible to estimate a saturated interaction model which considers all possible interaction variables because a high degree of multicollinearity would follow. Therefore, the number of interaction variables has to be restricted to few interactions, including the jointly dependent variables. In accordance with relevant literature we have also focused on the relationship variable (Petersen and Rajan, 1994; Berger and Udell, 1995; Elsas and Krahnen, 1998). ${ }^{5}$

\section{EMPIRICAL RESULTS}

5 Due to these drawbacks we have also estimated separate regressions for the pre- and post-liberalisation periods as a robustness check. This method principally includes all liberalisation effects but the degree of freedom in the separate estimates is lower, reducing the power of estimation. As findings are in line with the interaction approach, we do not report results here. 


\section{a. Specification of the Interaction Model}

In the following the results of an interaction model are reported using the threestage least squares method. The selection of the regressors in each equation follows a two-step procedure based on economic theory and statistical criteria. ${ }^{6}$ In order to test for simultaneity we apply the RESET version of the Hausman test (Baltagi, 1998, p.290). The tests reject exogeneity in both equations (see Table 4). Thus the two dimensions of lending decisions are jointly dependent and the application of a 3SLS approach is appropriate.

A last issue is the high heterogeneity in our data due to the inclusion of all kinds of loans from many banks with different lending policies. Resulting outliers can distort estimations. The classical outlier detection method is powerful when the data contain only one outlier and when only one reason is responsible. This cannot be expected in our heterogeneous sample. It seems therefore useful to follow Hadi and Son (1998) who developed a method for identifying multiple outliers in multivariate data. ${ }^{7}$ As we will see, the influence of this outlier variable is significant in both lending conditions' equations. The incorporation of the outlier variable considerably improves the goodness of specification.

\section{b. The Interest Rate Spread}

The 3SLS estimates of the coefficients of the interest rate spread equation are presented in the first column of Table 5. Presentation starts with the (non-)interacted variables and the time trend in order to emphasize the extent of the change brought

\footnotetext{
${ }^{6}$ In the first step we have incorporated among the available variables those as explanatory determinants which are expected as influential due to theoretical reasons, the same variables in both equations. In the second step, those variables are excluded which have $t$ values smaller than one because the inclusion reduces the adjusted determination coefficient (Haitovsky, 1969).

7 The main idea is to first form a basic subset of about half of the data which is presumably free of outliers, then to add observations that are consistent with the basic subset. To determine whether an observation is consistent with the basic subset, a suitable metric is chosen to measure the distance between each observation in the data and the centre of the observations in the basic subset. The method is implemented in two stages; the first is to find the basic subset, and the second is to test for the outliers. This procedure is iteratively repeated where in each step a new basic subset is determined. One can use the Mahalanobis distance where the $\mathrm{Kx} 1$ observation vector of each individual $\mathrm{i}$ with $\mathrm{K}$ outlier determinants, $\mathrm{x}_{\mathrm{i}}$, outside the basic subset will be compared with the mean vector of the basic subset, $x_{b}$, weighted by the sample covariance matrix of the basic subset, $\mathrm{S}_{\mathrm{b}}$. One should incorporate only those variables which are important for the substantial analysis.
} 
about by financial liberalisation; thereafter, we discuss significant variables in the order of their presentation in Table 1.

The first significant variable is collateral, indicating that loans which are secured by more collateral get more favourable interest rates. Collateral thus serves as a means to reduce the risk of a loan. However, the interaction of time with collateral i.e. the "(1994-96) Collateral" variable - indicates that the specific effect of collateral since the major liberalisation took place (coefficient of 14.58) is almost exactly the opposite of the overall effect discussed at the beginning (-15.87). This means that the average impact of collateral is almost balanced in the later years 1994-96. This is consistent with hypothesis 2 that traditional elements of banking, such as reliance on the simple risk aversion concept of collateral lose importance due to the induced modernisation process.

The same change is found for relationship banking: the house bank status variable seems to reflect the downside of relationship lending (Boot, 2000) as house banks charges higher interest rates, reflecting a lock-in effect (see also Menkhoff et al., 2006). Again, the interaction of time and the house bank variable shows that traditional relationship banking became significantly weaker after liberalisation which supports hypothesis 2 . This brings us to the time trend variable in this 3SLS regression which has the expected significant sign, i.e. declining interest rates, in contrast to simple descriptive and bivariate statistics presented in Tables 2 and 3 , thus supporting hypothesis 1 .

This difference between rising interest rate spread in the descriptive statistics but declining spread in the regression may deserve some consideration. In essence there are two reasons explaining the difference. First, the regression approach considers further variables which cautiously indicate that the selection of borrowers became rather riskier: firms became smaller, clearly younger and relation duration decreased (see Table 2). Thus interest rate spread increased but it decreased when we control for relevant determinants. Second, the interdependence between spread and collateral and the strong correlations between collateral, time and the interacted variable (1994-96 Collateral) cause a severe econometric specification problem for any bivariate estimation of the time influence on spread: this specification is expected to produce insignificant or even wrongly signed coefficients.

Turning to the remaining variables, we find that a larger number of banking relationships obviously improves competition, leading to lower interest rates. Moreover, 
the company variable "assets" - indicating size - is also related to better prices; this is the standard finding in the literature. The second company variable considered here, company age, serves as the identifying variable in this regression and has the expected sign, i.e. older firms are regarded as less risky and thus get lower lending rates. ${ }^{8}$ Among the "other variables", we find banks of larger size - consistent with the negotiation power of large banks - to charge higher interest rates. ${ }^{9}$ Finally, the outlier variable is statistically important to capture heterogeneity. If we would neglect the outlier variable other coefficients would be biased but this variable we cannot be interpreted further in an economic sense. ${ }^{10}$

What could be disturbing in this environment is the consideration of risk. It had been mentioned before that conventional risk proxies had not been important in explaining bank lending in pre-crisis Thailand (but may have become since then). Therefore, company size, company age and collateral serve as indirect proxies for riskiness of a loan. The finding that at the same time interest rate spreads (controlled for indirect risk factors and other determinants) and collateral requirements were declining, indicates that risk may be priced less than before. Unfortunately, we do not have better information about true riskiness of borrowers but this result is consistent with concerns expressed via hypothesis 3 .

In summary, the coefficients by and large show the expected impact. Liberalisation seems to work as there is a trend of declining interest rates in the 3SLS estimates and a lower impact of traditional collateral-based and relationship-based lending, but a possibly unwelcome effect may be a declining price of risk. Is this picture matched by findings regarding collateral requirements?

\section{c. Collateral}

The second dimension of lending decisions considered here is the degree of collateral required. Regression results are presented in column 2 of Table 5 . We

\footnotetext{
8 If we would exchange the identifying variables between both regressions, t-values would decrease considerably.

9 The bank size variable is coded according to the convention in the Thai banking market where three categories, i.e. small, medium-sized and large banks are distinguished. Banks did not change between categories during the 1990s.

10 Industry dummies are not reported and are all insignificant in this specification. The classification of industries is defined by the Bank of Thailand, the supervisory authority. There are 12 industries distinguished, i.e. agriculture, banking and finance, construction, export, import, manufacturing, mining, personal consumption, public utilities, real estate, service and wholsesale/retail trade.
} 
have used the same variables as for the interest rate regression with the necessary exception of the endogenous and identifying variables.

Discussing results, interest rate spread mirrors the finding from above because higher interest rates are related to lower collateral. These two variables are inversely related and interdependent. This means in the collateral equation that lower interest rates induce higher collateral requirements and more collateral serves to reduce riskiness of a loan. Again, we find a significant interaction variable, i.e. the interest rate spread becomes much less important over time in explaining collateral requirements. Turning to the house bank variable, house banks tend to require more collateral, indicating a lock-in effect as in the interest rate spread-equation, although the coefficient is not significant. Again, this effect (if existent) is weakened by liberalisation as the interaction variable shows a declining importance of house banks as a collateral determinant. Both findings are in accord with hypothesis 2. Finally, we also find a significant time trend, here in conformity with hypotheses 1 and 2: collateral requirements tend to decrease over time. In analogy to the interest rate spreadequation, this result is different from simple descriptive statistics because of the same reasons mentioned before, i.e. considering more relevant determinants and using an interdependent approach.

Turning to the further variables, more bank relations help to reduce the collateral burden. Also larger firms need less collateral as well as tentatively (but not significantly) firms with a higher availability of credit which is the identifying variable here. Both company variables can be safely interpreted as indicators of less risky firms. Moreover, heterogeneity is important as the significant outlier dummy indicates. ${ }^{11}$ A possible downside of this structural change seems to be that collateral was less used as a buffer against risk without any substitute developing - this is consistent with hypothesis 3 although we are aware that there is better information about borrowers' riskiness missing.

\section{d. Robustness Tests}

In order to check robustness of core findings we discuss five respective tests in the following. Core findings are not sensitive to these tests. We prefer the bench-

\footnotetext{
11 Industry dummies are again insignificant with the exception that loans to the banking and the export sector use less collateral, possibly indicating less riskiness of these sectors.
} 
mark specification presented in Table 5 because it seems econometrically advantageous to alternatives as indicated by the Akaike criterion.

As first robustness test, the time effect of financial liberalization is captured by a financial liberalisation dummy that becomes one for the later years and zero for the years 1992 and 1993. To make results for various robustness tests easier comparable we simply add this variable to the benchmark specification shown in Table 5 . Results are given as specification (1) in Table 6, the new variable is shown towards the bottom of the table. Reassuringly, the inclusion of this additional variable causes only one important change that is the insignificance of the formerly highly significant time trend variable which is obviously a substitute for the time dummy. All other variables keep their significance (with one marginal exception) and order of magnitude. ${ }^{12}$

Second, we add the number of banks interacted with time as additional variable. This is motivated by the fact that the number of banks was increasing overall in the banking system, although not necessarily for all customers as can be seen from descriptive statistics in Table 2. It may be thus not surprising that the new specification (2) in Table 6 provides virtually no change compared to the benchmark.

As a third robustness test we include the duration of relation between bank and borrower as a further variable indicating relationship banking (see e.g. Menkhoff et al., 2006). The result is given as specification (3) in Table 6 and shows again no important difference with the benchmark specification. ${ }^{13}$

Fourth, we have tested sensitivity of findings with respect to regrouping of the industry dummies. However, there is not much to report as coefficients remain almost always insignificant. Only in extreme classifications, i.e. grouping one sector against all others, we find that the export industry receives somewhat better terms, possibly indicating its limited riskiness. ${ }^{14}$

\footnotetext{
12 The exception is the interacted house bank status which was formerly significant at the 10 per cent level in the collateral equation.

${ }_{13}$ There is also an econometric argument against inclusion as endogeneity tests show that interest rate spread and relation duration are interdependent. A long relation duration induces lower interest rates on the one hand and if interest rate spread is low, firms are willing to stay with their house bank. Therefore, one may argue that relation duration is instrumented by the house bank dummy.

14 There are at least two possible interpretations: first, the number of cases is limited which makes it difficult to infer significant coefficients from noisy data. Second, industry classification is used by the supervisory authority to require directed credit, such as minimum lending to agriculture, which may set incentives for banks to classify loans accordingly.
} 
Finally, we have checked the importance of interaction variables by two extreme specifications (see Appendix). On the one hand, we stick to the benchmark but delete the three interaction variables. This results in mostly insignificant coefficients, where the antagonistic time effects - i.e. period 1992-93 versus period 1994-96 - are compensated. This makes the analysis meaningless. On the other hand, we reduce the benchmark specification to its minimum by keeping only the interdependent variables, the identifying variables, the time trend and the interaction variables. This results in mostly significant coefficients with the expected signs. ${ }^{15}$ We thus conclude that results basically hold if only the main determinants are incorporated but they are damaged if interactions are suppressed. Obviously, the consideration of time-related interaction variables is a useful measure to understand liberalization induced by changes in Thailand's bank lending during the 1990s.

\section{e. Discussion of Policy Lessons}

Our study covers a period in Thailand's economic history that seemed to be a golden time. Growth rates per year were about a steady 8 per cent between 1992 and 1995 and even the 6 per cent of 1996 appears very desirable from the viewpoint of most other countries. Inflation rates also were nearly constant at around 5 per cent and the budget closed rather with surplus than deficit. The financial liberalisation being pursued at this time intended to strengthen competition (hypothesis 1) and to expedite the ongoing structural change (hypothesis 2 ) in order to ensure further growth. In contrast to the banks operating during these years, however, we know today that something must have gone wrong during these boom years. Macroeconomic studies conducted ex post emphasise factors such as overlending (Corsetti et al., 1999), increased vulnerability (Warr, 1999; Vines and Warr, 2003) or wrong incentives (Dooley, 2000) as relevant determinants of the crisis in 1997 - it is always a common theme that risk considerations (pointed at in hypothesis 3 ) did not receive enough attention (see also Rajan, 2001; Reynolds et al., 2002).

Our study allows for a test of the three hypotheses mentioned above. Due to the nature of micro data we are able to draw policy lessons that are more detailed than in most of the earlier literature. To start with the general lessons, findings give

\footnotetext{
${ }^{15}$ If we include the house bank variable, non-interacted and interacted, results do hardly change but the AIC-value becomes worse. Thus, we do not present this specification in the Appendix.
} 
strong support to hypothesis 1 (better lending terms), some support to hypothesis 2 (more modern behaviour) and some indicative support to hypothesis 3 (less risk assessment). Findings for the Thai case thus support the view that financial liberalisation can be very beneficial but also causes fragility (Stiglitz, 2000, 2004; Weller, 2001) and urgently requires an appropriate building up of risk management abilities (see also Williamson and Mahar, 1998; Auerbach and Siddiki, 2004; Krueger, 2005). In this vein, it is obvious that risk management at the bank level as well as prudential regulatory infrastructure was insufficient in the first half of the 1990s (Caprio and Honohan, 1999). There are further possible lessons which may be helpful in the future:

(1) Aside from shortcomings in their risk management abilities the findings on lending determinants of Thai commercial banks do not seem to signal malfunction when compared to experiences from industrialised economies (see also Menkhoff and Suwanaporn, 2007). This reduces the possible benefit that can be gained from financial liberalisation and thus provides time to carefully prepare policy measures.

(2) It is noteworthy that banks did not - different from other cases - operate outright inefficiently (see La Porta et al., 2003, on Mexico; Khwaja and Mian, 2005, on Pakistan). This antagonism suggests that financial liberalisation should be designed on a case by case basis.

(3) Beyond the often reported liberalisation induced decline in interest rates (Bekaert et al., 2005) we observe that also the interest rate spread is narrowing. This may cause incentives to regroup business into more risky business with higher margins. We observe, indeed, that spreads decline when controlled for the kind of business but increased at face value. This is consistent with the interpretation that banks followed a more risky strategy and calls for counterbalancing measures.

(4) The decline in collateral indicates that loans became more easily available. This is a wanted effect of liberalisation on the one hand. On the other, collateralbased lending can be interpreted as a simple form of risk consideration in the lending terms. Thus, the reduction of collateral-based lending may call for other measures of risk consideration. Available credit files, interviews conducted as well as the massive credit defaults indicate that bank lending in Thailand at that time was possibly short of other forms of risk consideration that could have substituted the simple collateralbased lending. 
(5) The fact of larger banks charging more restrictive lending terms, i.e. higher interest rate and more collateral at the same time, indicates negotiation power of large banks. This is often found in emerging markets and indicates that measures of competition policy (different from general liberalisation) could improve lending conditions and in this sense serve as a (partial) substitute to aggressive financial liberalisation.

(6) In Thailand we observe financial modernisation in two dimensions that is less collateral-based lending and less importance of relationship lending. Both traditional elements can be understood as reflection of more opaque financial markets in developing countries. In this sense they represent appropriate institutions helping to overcome asymmetric information. Modernisation should secure that new institutions are in place before these old ones are pushed back.

\section{CONCLUSIONS}

Our credit file data provide an instrument to understand the lending decisions of Thai commercial banks during the phase of financial liberalisation from 1992 to 1996. Overall, our findings indicate that the costs of liberalisation-induced structural change may be higher than often assumed and may call for a less radical liberalisation policy than being practiced in the 1990s (see Bird, 2005).

We provide evidence on four major findings: first liberalisation lowers interest rate spreads and reduces collateral requirements (hypothesis 1). Second, liberalisation helps to modernise decision making in the sense that the very important role of collateral-based lending and relationship lending is reduced (hypothesis 2). Third, there is indicative (although not directly revealing) evidence that risk taking in lending has increased without any indication that methods of risk control had improved (hypothesis 3). After liberalisation, banks seem to shift their business into more risky fields and reduce collateral, i.e. their main buffer against losses from default. Fourth, it seems well justified to apply a simultaneous regression approach which is new to this literature. Thai banks' lending is interdependent in the two dimensions of pricing and collateral requirements, a finding that may apply to other emerging countries with high importance of collateral-based lending as well.

These findings provide obvious lessons to improve financial liberalisation in the future. To generalize the above discussed six policy lessons, it seems important to recognize that bank lending in emerging markets may be functional with respect to 
existing institutions, such as collateral-based and relationship lending. Therefore, financial liberalisation as a policy inducing structural change has to make sure ex ante that new institutions will replace old ones.

In order to better design financial liberalisation in the future it would be most useful to increase our knowledge from credit file studies beyond Thailand and Mexico (La Porta et al., 2003). Which experiences are country-specific and what can be learned from other cases?

\section{REFERENCES}

Aizenman, J. (2005), 'Financial Liberalisations in Latin America in the 1990s: A Reassessment', The World Economy, 28, 7, 959-983.

Arestis, P., P. Demetriades, B. Fattouh and K. Mouratidis (2002), 'The Impact of Financial Liberalization Policies on Financial Development: Evidence from Developing Countries', International Journal of Finance and Economics, 7, 2, 109-121.

Auerbach, P. and J.U. Siddiki (2004), 'Financial Liberalisation and Economic Development: An Assessment', Journal of Economic Surveys, 18, 3, 231-265.

Baltagi, B.H. (1998), Econometrics (New York: Springer).

Bartolini, L. and A. Drazen (1997), 'Capital-Account Liberalization as a Signal', American Economic Review, 87, 1, 138-154.

Bekaert, G., C.R. Harvey and C. Lundblad (2005), 'Does Financial Liberalization Spur Growth?', Journal of Financial Economics, 77, 3-55.

Berger, A.N. and G.F. Udell (1995), 'Relationship Lending and Lines of Credit in Small Firm Finance', Journal of Business, 68, 3, 351-381.

Bird, G. (2005), 'Over-Optimism and the IMF', The World Economy, 28, 9, 13551373.

Bongini, P., S. Claessens and G. Ferri (2001), 'The Political Economy of Distress in East Asian Financial Institutions', Journal of Financial Services Research, 19, 1, 5-25.

Boot, A.W.A. (2000), 'Relationship Banking: What Do We Know?', Journal of Financial Intermediation, 9, 1, 7-25.

Caprio, G. and P. Honohan (1999), 'Restoring Banking Stability: Beyond Supervised Capital Requirements', Journal of Economic Perspectives, 13, 4, 43-64.

Chari, A. and P.B. Henry (2002), 'Capital Account Liberalization: Allocative Efficiency or Animal Spirit?', NBER Working Paper, No.8908.

Charoenseang, J. and P. Manakit (2002), 'Financial Crisis and Restructuring in Thailand', Journal of Asian Economics, 13, 597-613.

Claessens, S., A. Demirgüç-Kunt and H. Huizinga (2001), 'How Does Foreign Entry Affect the Domestic Banking Market?', Journal of Banking and Finance, 25, 891-911.

Corsetti, G., P. Pesenti and N. Roubini (1999), 'Paper Tigers? A Model of the Asian Crisis', European Economic Review, 43, 1211-1236. 
Cull, R. (2001), 'Financial-Sector Reform: What Works and What Doesn't', Economic Development and Cultural Change, 49, 2, 269-290.

Demetriades, P.O. and K.A. Hussein (1996), 'Financial Development and Economic Growth: Cointegration and Causality Tests for 16 Countries', Journal of Development Economics, 51, 387-511.

Demetriades, P.O. and K. Luintel (2001), 'Financial Restraints in the South Korean Miracle', Journal of Development Economics, 64, 459-479.

Demirgüç-Kunt, A. and E. Detragiache (1999), 'Financial Liberalization and Financial Fragility', Annual World Bank Conference on Development Economics, Washington D.C., 303-331.

Dooley, M.P. (2000), 'A Model of Crises in Emerging Markets', Economic Journal, $110,256-272$.

Eichengreen, B. (2001), 'Capital Account Liberalization: What Do the Cross-Country Studies Tell Us?', World Bank Economic Review, 15, 3, 341-365.

Elsas, R. and J.P. Krahnen (1998), 'Is Relationship Lending Special? Evidence from Credit-File Data in Germany', Journal of Banking and Finance, 22, 12831316.

Frenkel, M. and L. Menkhoff (2004), 'Are Foreign Institutional Investors Good for Emerging Markets?', The World Economy, 27, 1275-1293.

Fry, M. (1997), 'In Favour of Financial Liberalisation', Economic Journal, 107, 754777.

Gelos, R.G. and J. Roldós (2004), 'Consolidation and Market Structure in Emerging Market Banking', Emerging Markets Review, 5, 1, 39-59.

Greene, W.H. (2003), Econometric Analysis, $5^{\text {th }}$ ed. (New York: Prentice Hall).

Hadi, A.S. and M.S. Son (1998), 'Detection of Unusual Observations in Regression and Multivariate Data', in: A. Ullah and D.E.A. Giles (eds.), Handbook of Applied Economic Statistics (New York: Marcel Dekker), 441-463.

Haitovsky, $Y$. (1969), 'A Note on the Maximization of $\mathrm{R}^{2}$ ', American Statistician, 23, 20-21.

Henry, P.B. (2006), 'Capital Account Liberalization: Theory, Evidence and Speculation', NBER Working Paper, No.12698.

Jansen, W.J. (2004), 'What Do Capital Inflows Do? Dissecting the Transmission Mechanism for Thailand, 1980-1996', Journal of Macroeconomics, 25, 4, 457-480.

Kaminsky, G.L. and C.M. Reinhart (1999), 'The Twin Crises: The Causes of Banking and Balance-of-Payments Problems', American Economic Review, 89, 3, 473-500.

Kaminsky, G.L. and S. Schmukler (2002), 'Short-run Pain, Long-run Gain - The Effects of Financial Liberalization', World Bank Policy Research Working Paper No.2912, June.

Krueger, A.O. (2005), 'De Tocqueville's 'Dangerous Moment': The Importance of Getting Reforms Right', The World Economy, 28, 6, 749-763.

Kwaja, A.I. and A. Mian (2005), 'Do Lenders Favor Politically Connected Firms? Rent Provision in an Emerging Financial Market', Quarterly Journal of Economics, 120, 4, 1371-1411.

La Porta, R., F. López-de-Silanes and G. Zamarripa (2003), 'Related Lending', Quarterly Journal of Economics, 118, 1, 231-268.

Menkhoff, L. (2000), 'Bad Banking in Thailand? An Empirical Analysis of Macro Indicators', Journal of Development Studies, 36, 5, 135-168. 
Menkhoff, L., D. Neuberger and C. Suwanaporn (2006), 'Collateral-Based Lending in Emerging Markets: Evidence from Thailand', Journal of Banking and Finance, 30, 1, 1-21.

Menkhoff, L. and C. Suwanaporn (2007), 'On the Rationale of Bank Lending in PreCrisis Thailand', Applied Economics, forthcoming.

Quinn, D.P. (1997), 'The Correlates of Changes in International Financial Regulation', American Political Science Review, 91, 531-551.

Petersen, M.A. and R.G. Rajan (1994), 'The Benefits of Lending Relationships: Evidence from Small Business Data', Journal of Finance, 44, 1, 3-37.

Petersen, M.A. and R.G. Rajan (1995), 'The Effect of Credit Market Competition on Lending Relationships', Quarterly Journal of Economics, 110, 407-443.

Rajan, R.S. (2001), '(Ir)Relevance of Currency-Crisis Theory to the Devaluation and Collapse of the Thai Baht', Princeton Studies in International Economics, No.88, Princeton University.

Reynolds, S., R. Fowles, J. Gander, W. Kunaporntham and S. Ratanakomut (2002), 'Forecasting the Probability of Failure of Thailand's Financial Companies in the Asian Financial Crisis', Economic Development and Cultural Change, 51, 1, 237-246.

Stiglitz, J.E. (2000), 'Capital Market Liberalization, Economic Growth and Instability', World Development, 28, 1075-1086.

Stiglitz, J.E. (2004), 'Capital-Market Liberalization, Globalization, and the IMF', Oxford Review of Economic Policy, 20, 1, 57-71.

Tornell, A. and F. Westermann (2005), Boom-Bust Cycles and Financial Liberalization (Cambridge et al.: MIT Press).

Vines, D. and P. Warr (2003), 'Thailand's Investment-Driven Boom and Crisis', Oxford Economic Papers, 55, 440-466.

Warr, P. (1999), 'What Happened to Thailand?', The World Economy, 22, 5, 631650.

Weller, C.E. (2001), 'Financial Crisis after Financial Liberalisation: Exceptional Circumstances or Structural Weakness?', Journal of Development Studies, 38, 1, 98-127.

Williamson, J. and M. Mahar (1998), 'A Survey of Financial Liberalization', Princeton Essays in International Finance, No.211, Princeton University.

World Bank (2001), Finance for Growth: Policy Choices in a Volatile World (Oxford et al.: Oxford University Press). 
TABLE 1. Variable definitions

Variable Description

Dependent variables

Interest rate spread (IRS)

Interest rate spread over minimum overdraft rate (MOR)

Collateral

Collateral value as percentage of the line of credit granted

Relationship variables

House bank status

Dummy variable ( $=1$ if bank considers itself as a house bank of the borrower; $=0$ if otherwise)

Number of banks that lend to the borrower

The number of banks that the borrower has relationship with

Relation duration

The number of years of bank-borrower relationship prior to the credit decision

\section{Company variables}

Assets

The latest book value of assets of the firm prior to the credit decision

Age

Number of years that the borrower has been in operation prior to the credit decision

Credit availability Volume of the line of credit (L/C) granted in relation to the sum of liabilities plus $\mathrm{L} / \mathrm{C}$

Other variables

Bank size

Count variable $(=1$ for the three smallest banks, $=2$ for the medium-sized banks; $=3$ for the three largest banks

Outlier

Dummy variable ( $=1$ if the observation is a multivariate outlier; $=0$ otherwise)

Industry j Dummy (=1 if borrower stems from industry j)

Time variables

Time trend

Count variable (1 for 1992 up to 5 for 1996)

Interactive variables

Dummy variable (=0 if year 1992 or $1993 ;=1$ if year 1994-96) 
TABLE 2. Descriptive statistics: mean and standard deviation

\begin{tabular}{|c|c|c|c|c|c|}
\hline Variables & 1992 & 1993 & 1994 & 1995 & 1996 \\
\hline Interest rate spread & $\begin{array}{c}0.697 \\
(1.100)\end{array}$ & $\begin{array}{c}0.541 \\
(0.925)\end{array}$ & $\begin{array}{c}0.788 \\
(1.105)\end{array}$ & $\begin{array}{c}0.915 \\
(1.279)\end{array}$ & $\begin{array}{c}0.720 \\
(1.107)\end{array}$ \\
\hline Collateral & $\begin{array}{c}0.502 \\
(0.422)\end{array}$ & $\begin{array}{c}0.437 \\
(0.438)\end{array}$ & $\begin{array}{c}0.507 \\
(0.411)\end{array}$ & $\begin{array}{c}0.574 \\
(0.411)\end{array}$ & $\begin{array}{c}0.535 \\
(0.429)\end{array}$ \\
\hline House bank status & $\begin{array}{c}0.562 \\
(0.500)\end{array}$ & $\begin{array}{c}0.448 \\
(0.501)\end{array}$ & $\begin{array}{c}0.510 \\
(0.503)\end{array}$ & $\begin{array}{c}0.487 \\
(0.501)\end{array}$ & $\begin{array}{c}0.470 \\
(0.501)\end{array}$ \\
\hline $\begin{array}{l}\text { Number of banks that } \\
\text { lend to the borrower (In) }\end{array}$ & $\begin{array}{c}1.076 \\
(0.873)\end{array}$ & $\begin{array}{c}1.228 \\
(0.888)\end{array}$ & $\begin{array}{c}1.050 \\
(0.681)\end{array}$ & $\begin{array}{c}1.125 \\
(0.826)\end{array}$ & $\begin{array}{c}1.121 \\
(0.826)\end{array}$ \\
\hline Relation duration & $\begin{array}{l}10.436 \\
(6.615)\end{array}$ & $\begin{array}{l}11.455 \\
(7.659)\end{array}$ & $\begin{array}{c}8.173 \\
(6.998)\end{array}$ & $\begin{array}{c}7.910 \\
(6.175)\end{array}$ & $\begin{array}{c}6.238 \\
(5.352)\end{array}$ \\
\hline Assets (In) & $\begin{array}{c}5.505 \\
(1.938)\end{array}$ & $\begin{array}{c}5.841 \\
(1.843)\end{array}$ & $\begin{array}{c}5.552 \\
(2.092)\end{array}$ & $\begin{array}{l}5.471 \\
(2.079)\end{array}$ & $\begin{array}{l}5.503 \\
(2.018)\end{array}$ \\
\hline Age & $\begin{array}{c}15.014 \\
(10.272)\end{array}$ & $\begin{array}{c}18.134 \\
(12.464)\end{array}$ & $\begin{array}{c}14.198 \\
(10.209)\end{array}$ & $\begin{array}{c}14.987 \\
(11.115)\end{array}$ & $\begin{array}{c}13.098 \\
(10.226)\end{array}$ \\
\hline Credit availability & $\begin{array}{c}0.346 \\
(0.274)\end{array}$ & $\begin{array}{c}0.278 \\
(0.247)\end{array}$ & $\begin{array}{c}0.350 \\
(0.265)\end{array}$ & $\begin{array}{c}0.361 \\
(0.261)\end{array}$ & $\begin{array}{c}0.334 \\
(0.254)\end{array}$ \\
\hline Bank size & $\begin{array}{c}2.301 \\
(0.660)\end{array}$ & $\begin{array}{c}2.239 \\
(0.720)\end{array}$ & $\begin{array}{c}2.125 \\
(0.743)\end{array}$ & $\begin{array}{l}2.107 \\
(0.860)\end{array}$ & $\begin{array}{c}2.159 \\
(0.893)\end{array}$ \\
\hline
\end{tabular}


TABLE 3. Characterisation of pre- and post-BIBF-introduction loans

\begin{tabular}{lccccc}
\hline Variable & & Observations & Mean & Standard deviation & $\mathrm{t}$ \\
Interest rate spread & $1992 / 93$ & 140 & 0.622 & 1.019 & $-1.78^{* *}$ \\
& $1994-96$ & 410 & 0.807 & 1.173 & \\
Collateral & $1992 / 93$ & 140 & 0.471 & 0.429 & $-1.73^{* *}$ \\
& $1994-96$ & 410 & 0.543 & 0.418 & \\
\hline
\end{tabular}

Note - One-tailed hypothesis tests on difference between pre- and post-BIBF period; $t$ means asymptotic $t$ statistics.

${ }^{* * *}$ - significant at $\alpha=0.01 ;{ }^{* *}$ - significant at $\alpha=0.05 ;{ }^{*}$ - significant at $\alpha=0.10$.

\section{TABLE 4. Tests for exogenity of dependent variables}

\begin{tabular}{lcc}
\hline & \multicolumn{2}{c}{$\begin{array}{c}\text {-values on hypothesis testing } \\
\mathrm{H}_{0} \text { : exogeneity }\end{array}$} \\
Dependent variable & Interest rate spread & Collateral \\
\hline Interest rate spread (IRS) & - & 0.00 \\
Collateral (COL) & 0.00 & - \\
\hline
\end{tabular}


TABLE 5. Three-stage least squares estimates of the interaction regression model

\begin{tabular}{|c|c|c|}
\hline \multirow[t]{2}{*}{ Independent variables } & \multicolumn{2}{|c|}{ Dependent variables } \\
\hline & Interest rate spread & Collateral \\
\hline Interest rate spread & & $-4.01(1.50)^{\star * *}$ \\
\hline $\begin{array}{r}\text { (1994-96) Interest rate } \\
\text { spread }\end{array}$ & & $3.37(1.28)^{\star * *}$ \\
\hline Collateral & $-15.87(4.10)^{\star \star \star}$ & \\
\hline (1994-96) Collateral & $14.58(3.83)^{\star * \star}$ & \\
\hline House bank status & $3.02(1.07)^{\star * *}$ & $0.56(0.40)$ \\
\hline $\begin{array}{r}\text { (1994-96) House bank } \\
\text { status }\end{array}$ & $-4.10(1.31)^{\star \star *}$ & $-0.93(0.53)^{*}$ \\
\hline Time trend & $-1.29(0.37)^{\star \star \star}$ & $-0.41(0.18)^{\star *}$ \\
\hline $\begin{array}{l}\text { Number of banks that } \\
\text { lend to the borrower (In) }\end{array}$ & $-1.01(0.30)^{\star \star \star}$ & $-0.32(0.16)^{\star *}$ \\
\hline Assets (In) & $-0.37(0.10)^{\star \star \star}$ & $-0.56(0.21)^{\star \star *}$ \\
\hline Age & $-0.03(0.02)^{*}$ & \\
\hline Credit availability & & $-1.10(0.69)$ \\
\hline Bank size & $0.52(0.20)^{* * *}$ & $0.41(0.18)^{* *}$ \\
\hline Outlier & $1.28(0.63)^{\star *}$ & $1.50(0.65)^{\star *}$ \\
\hline Industry dummies & Yes & Yes \\
\hline Constant & $10.07(2.26)^{\star \star \star}$ & $5.87(2.09)^{* * *}$ \\
\hline AIC & & \\
\hline
\end{tabular}

Note. Standard errors in parentheses; ${ }^{* * *}$ - significant at $\alpha=0.01$; ${ }^{* *}$ - significant at $\alpha=0.05$; ${ }^{\text {significant at }}$ $\alpha=0.10$ 
TABLE 6. Robustness tests

Independent variables

Dependent variables

(1)

(2)

(3)

IRS Collateral IRS Collateral IRS Collateral

\begin{tabular}{|c|c|c|c|c|c|c|}
\hline $\begin{array}{r}\text { Interest rate spread } \\
\text { (IRS) }\end{array}$ & & $\begin{array}{r}-3.47 \\
(1.58)^{\star *}\end{array}$ & & $\begin{array}{r}-4.03 \\
(1.51)^{\star \star \star}\end{array}$ & & $\begin{array}{r}-5.69 \\
(2.38)^{\star \star}\end{array}$ \\
\hline $\begin{array}{r}\text { (1994-96) Interest rate } \\
\text { spread }\end{array}$ & & $\begin{array}{r}2.98 \\
(1.38)^{* *}\end{array}$ & & $\begin{array}{r}3.39 \\
(1.29)^{\star \star \star}\end{array}$ & & $\begin{array}{l}4.76 \\
(2.02)^{* *}\end{array}$ \\
\hline Collateral & $\begin{array}{r}-20.53 \\
(6.87)^{* * *}\end{array}$ & & $\begin{array}{r}-15.86 \\
(4.10)^{\star * *}\end{array}$ & & $\begin{array}{r}-15.50 \\
(4.12)^{\star \star \star}\end{array}$ & \\
\hline (1994-96) Collateral & $\begin{array}{r}19.62 \\
(6.76)^{\star \star \star}\end{array}$ & & $\begin{array}{r}14.57 \\
(3.83)^{\star \star \star}\end{array}$ & & $\begin{array}{r}14.44 \\
(3.85)^{\star \star \star}\end{array}$ & \\
\hline House bank status & $\begin{array}{r}1.79 \\
(1.03)^{*}\end{array}$ & $\begin{array}{r}0.06 \\
(0.30)\end{array}$ & $\begin{array}{r}3.01 \\
(1.07)^{* * *}\end{array}$ & $\begin{array}{r}0.55 \\
(0.40)\end{array}$ & $\begin{array}{r}3.11 \\
(1.09)^{* * *}\end{array}$ & $\begin{array}{r}0.90 \\
(0.60)\end{array}$ \\
\hline $\begin{array}{r}\text { (1994-96) House bank } \\
\text { status }\end{array}$ & $\begin{array}{r}-2.51 \\
(1.25)^{\star *}\end{array}$ & $\begin{array}{l}-0.20 \\
(0.37)\end{array}$ & $\begin{array}{r}-4.09 \\
(1.31)^{* \star *}\end{array}$ & $\begin{array}{r}-0.93 \\
(0.54)^{*}\end{array}$ & $\begin{array}{r}-4.15 \\
(1.32)^{* * *}\end{array}$ & $\begin{array}{r}-1.43 \\
(0.81)^{*}\end{array}$ \\
\hline Time trend & $\begin{array}{r}-0.15 \\
(0.24) \\
\end{array}$ & $\begin{array}{r}-0.05 \\
(0.10)\end{array}$ & $\begin{array}{r}-1.30 \\
(0.37)^{\star \star \star}\end{array}$ & $\begin{array}{r}-0.42 \\
(0.18)^{\star \star}\end{array}$ & $\begin{array}{r}-1.31 \\
(0.37)^{\star \star \star}\end{array}$ & $\begin{array}{r}-0.61 \\
(0.28)^{\star *}\end{array}$ \\
\hline $\begin{array}{l}\text { Number of banks that } \\
\text { lend to the borrower (In) }\end{array}$ & $\begin{array}{r}-1.37 \\
(0.46)^{\star \star \star}\end{array}$ & $\begin{array}{c}-0.31 \\
(0.15)^{\star *}\end{array}$ & $\begin{array}{r}-1.04 \\
(0.35)^{\star * *}\end{array}$ & $\begin{array}{l}-0.35 \\
(0.19)^{\star}\end{array}$ & $\begin{array}{r}-0.96 \\
(0.31)^{\star \star \star}\end{array}$ & $\begin{array}{r}-0.39 \\
(0.22)^{*}\end{array}$ \\
\hline Assets (In) & $\begin{array}{r}-0.35 \\
(0.11)^{* * *}\end{array}$ & $\begin{array}{r}-0.48 \\
(0.21)^{* *}\end{array}$ & $\begin{array}{r}-0.37 \\
(0.10)^{* \star *}\end{array}$ & $\begin{array}{r}-0.56 \\
(0.21)^{* \star *}\end{array}$ & $\begin{array}{r}-0.34 \\
(0.10)^{* * \star}\end{array}$ & $\begin{array}{r}-0.77 \\
(0.32)^{* \star}\end{array}$ \\
\hline Age & $\begin{array}{r}-0.04 \\
(0.02)^{*}\end{array}$ & & $\begin{array}{r}-0.03 \\
(0.02)^{*}\end{array}$ & & $\begin{array}{r}-0.02 \\
(0.02)\end{array}$ & \\
\hline Credit availability & & $\begin{array}{l}-0.95 \\
(0.66)\end{array}$ & & $\begin{array}{l}-1.10 \\
(0.70)\end{array}$ & & $\begin{array}{l}-1.61 \\
(1.05)\end{array}$ \\
\hline Bank size & $\begin{array}{r}0.39 \\
(0.23)^{*}\end{array}$ & $\begin{array}{r}0.31 \\
(0.16)^{\star *}\end{array}$ & $\begin{array}{r}0.52 \\
(0.20)^{* * *}\end{array}$ & $\begin{array}{r}0.42 \\
(0.18)^{\star \star}\end{array}$ & $\begin{array}{r}0.54 \\
(0.20)^{* \star \star}\end{array}$ & $\begin{array}{r}0.60 \\
(0.28)^{\star *}\end{array}$ \\
\hline Outlier & $\begin{array}{r}1.52 \\
(0.77)^{\star *}\end{array}$ & $\begin{array}{r}1.29 \\
(0.65)^{\star *}\end{array}$ & $\begin{array}{r}1.25 \\
(0.66)^{\star}\end{array}$ & $\begin{array}{r}1.48 \\
(0.66)^{* *}\end{array}$ & $\begin{array}{r}1.22 \\
(0.63)^{*}\end{array}$ & $\begin{array}{r}2.08 \\
(0.98)^{* *}\end{array}$ \\
\hline Industry dummies & Yes & Yes & Yes & Yes & Yes & Yes \\
\hline Constant & $\begin{array}{r}12.87 \\
(3.76)^{* \star \star}\end{array}$ & $\begin{array}{r}5.24 \\
(2.17)^{\star *}\end{array}$ & $\begin{array}{r}10.10 \\
(2.27)^{\star \star \star}\end{array}$ & $\begin{array}{r}5.94 \\
(2.12)^{\star \star \star}\end{array}$ & $\begin{array}{r}9.95 \\
(2.28)^{* \star *}\end{array}$ & $\begin{array}{r}8.24 \\
(3.34)^{\star *}\end{array}$ \\
\hline (1994-96) Dummy & $\begin{array}{r}-7.53 \\
(2.79)^{* * *}\end{array}$ & $\begin{array}{l}-1.48 \\
(0.76)^{*}\end{array}$ & & & & \\
\hline $\begin{array}{r}\text { (1994-96) Number of } \\
\text { banks ... (In) }\end{array}$ & & & $\begin{array}{r}0.01 \\
(0.05)\end{array}$ & $\begin{array}{r}0.01 \\
(0.03)\end{array}$ & & \\
\hline Relation duration & & & & & $\begin{array}{r}-0.04 \\
(0.03) \\
\end{array}$ & $\begin{array}{r}-0.04 \\
(0.02) \\
\end{array}$ \\
\hline AIC & 528 & & $522 \varepsilon$ & & 558 & 85 \\
\hline
\end{tabular}

Note. Standard errors in parentheses; ${ }^{* * *}$ - significant at $\alpha=0.01 ;{ }^{* *}$ - significant at $\alpha=0.05 ;{ }^{*}$ significant at $\alpha=0.10$ 


\section{APPENDIX. Further robustness tests}

\begin{tabular}{|c|c|c|c|c|}
\hline \multirow[t]{3}{*}{ Independent variables } & \multicolumn{4}{|c|}{ Dependent variables } \\
\hline & \multicolumn{2}{|c|}{ (1) } & \multicolumn{2}{|c|}{ (2) } \\
\hline & IRS & Collateral & IRS & Collateral \\
\hline $\begin{array}{r}\text { Interest rate spread (IRS) } \\
(1994-96) \text { Interest rate } \\
\text { spread }\end{array}$ & & $\begin{array}{r}0.50 \\
(0.28)^{*}\end{array}$ & & $\begin{array}{r}-1.42 \\
(0.50)^{\star \star \star *} \\
1.47 \\
(0.49)^{\star \star *}\end{array}$ \\
\hline $\begin{array}{r}\text { Collateral } \\
\text { (1994-96) Collateral }\end{array}$ & $\begin{array}{r}28.28 \\
(96.51)\end{array}$ & & $\begin{array}{r}-84.1253 \\
(27.30)^{\star \star \star} \\
71.91 \\
(24.69)^{\star \star *}\end{array}$ & \\
\hline House bank status & $\begin{array}{r}-4.03 \\
(12.99)\end{array}$ & $\begin{array}{r}0.22 \\
(0.07)^{\star \star \star}\end{array}$ & & \\
\hline \multicolumn{5}{|l|}{ (1994-96) House bank status } \\
\hline Time trend & $\begin{array}{r}-0.48 \\
(1.77)\end{array}$ & $\begin{array}{r}0.00 \\
(0.02)\end{array}$ & $\begin{array}{r}-9.20 \\
(3.24)^{* * *}\end{array}$ & $\begin{array}{r}-0.23 \\
(0.09)^{* * *}\end{array}$ \\
\hline $\begin{array}{r}\text { Number of banks that lend to } \\
\text { the borrower (In) }\end{array}$ & $\begin{array}{r}2.23 \\
(8.48)\end{array}$ & $\begin{array}{r}0.04 \\
(0.08)\end{array}$ & & \\
\hline Assets (In) & $\begin{array}{r}0.80 \\
(3.72)\end{array}$ & $\begin{array}{r}0.12 \\
(0.09)\end{array}$ & & \\
\hline Age & $\begin{array}{r}0.11 \\
(0.40)\end{array}$ & & $\begin{array}{r}-0.23 \\
(0.11)^{\star *}\end{array}$ & \\
\hline Credit availability & & $\begin{array}{r}0.30 \\
(0.21)\end{array}$ & & $\begin{array}{r}0.14 \\
(0.13)\end{array}$ \\
\hline Bank size & $\begin{array}{r}-0.35 \\
(2.37)\end{array}$ & $\begin{array}{l}-0.14 \\
(0.09)\end{array}$ & & \\
\hline Outlier & $\begin{array}{r}-0.14 \\
(3.56)\end{array}$ & $\begin{array}{l}-0.35 \\
(0.24)\end{array}$ & & \\
\hline Industry dummies & YES & YES & NO & NO \\
\hline Constant & $\begin{array}{r}-18.21 \\
(68.92) \\
\end{array}$ & $\begin{array}{r}-0.47 \\
(0.66) \\
\end{array}$ & $\begin{array}{r}51.38 \\
(17.03)^{\star \star \star}\end{array}$ & $\begin{array}{r}1.50 \\
(0.39)^{\star \star *}\end{array}$ \\
\hline AIC & & 5258.99 & & 3204.41 \\
\hline
\end{tabular}

Note. Standard errors in parentheses; ${ }^{* * *}$ - significant at $\alpha=0.01$; ${ }^{* *}$ - significant at $\alpha=0.05 ;{ }^{*}$ significant at $\alpha=0.10$ 